\title{
Microlepidoptera Caught in Traps Baited with Lures Containing Pear Ester and Acetic Acid in Hungary
}

\author{
J. K. JÓSVAI ${ }^{*}$, S. KOCZOR ${ }^{1}$, CS. SZABÓKY², M. LADÁNYI ${ }^{3}$ and M. TÓTH ${ }^{1}$ \\ ${ }^{1}$ Plant Protection Institute, Centre for Agricultural Research, Hungarian Academy of Sciences, \\ P.O.B. 102, H-1525, Hungary \\ ${ }^{2}$ Forest Research Institute, Várkerület 30/A, H-9600 Sárvár, Hungary \\ ${ }^{3}$ Department of Biometrics and Agricultural Informatics, Faculty of Horticultural Sciences, \\ Szent István University, Villányi Street 29-43, H-1118 Budapest, Hungary
}

(Received: 6 June 2016; accepted: 24 June 2016)

\begin{abstract}
The present research was undertaken to screen for field activity of ethyl-(E,Z)-2,4-decadienoate (pear ester, PE), acetic acid (AA) and the blend of this two components (PEAA) at locations, where high diversity of microlepidopteran species was presumed. By tendency of relative catches, microlepidopterans captured could be divided into two groups: in the first group the PEAA blend resulted in higher catches than single components (Hedya nubiferana, Ypsolopha scabrella and Notocelia trimaculana), while in the second group (Archips rosana, A. xylosteana, Ptycholoma lecheana and Tortrix viridana) only the presence of AA was responsible for attractivity.

In all species, both male and female specimens were caught. This result indicates a potential way to optimise female-targeted lures based on PEAA or AA for all these microlepidopterans that are all recorded as pests. On the other hand, the capture of the above moths in the traps raises the need for some taxonomic knowledge in evaluating captures in PEAA-baited traps currently use in agricultural practice for codling moth monitoring.
\end{abstract}

Keywords: Ypsolopha scabrella, Notocelia trimaculana, Archips spp., Ptycholoma lecheana, Tortrix viridana, attractant.

The combination of pear ester (E,Z-2,4-decadienoate; PE) and acetic acid (AA) is a known attractant for both male and female codling moths (Cydia pomonella L., Lepidoptera: Tortricidae) (see for example Landolt et al., 2007). This lure has the potential for application in monitoring the population of this highly important pest insect, resulting improved pest management strategies (Knight and Light, 2005a; Witzgall et al., 2008). However, the PEAA lure (the blend of PE and AA) has the advantage to attract both male and female codling moth as well, since being a feeding attractant, it is far less specific than the synthetic sex pheromone (Roelofs et al., 1971).

Pear ester is a volatile constituent of several plants (pear - Jennings et al., 1964; ripe apple - Berger et al., 1984; quince - Schimizu and Yoshihara, 1977) and it is thought to have a role also in oviposition and host plant finding behaviour of adult codling moths (Landolt et al., 2007).

\footnotetext{
* Corresponding author; e-mail: josvai.julia@agrar.mta.hu
} 
Apart from codling moth, there is a relatively wide array of related microlepidoptera feeding on the above or related host plants (Mészáros et al., 1995). Some of these moths could also use the same two compounds for orienting to host plants or to oviposition sites. In North America, PE was reported not to be significantly more attractive to other insect species than codling moth (Light et al., 2001; Knight and Light, 2005b; Light and Knight, 2005). However, in Europe, PE on its own has been reported to be attractive to several other tortricid pest species like Cydia splendana Hübner, C. fagiglandana Zoller, Hedya nubiferana Haworth and Pammene fasciana L. (Coracini et al., 2004; Schmidt et al., 2007).

Acetic acid is a microbial fermentation product of sweet baits (Utrio and Eriksson, 1977) and as adult, C. pomonella is known to feed on fermented sugar sources (Wenninger and Landolt, 2011). AA may play a role in the food finding behaviour of this species as well (Landolt and Guédot, 2008). Moreover, AA, by itself, is a weak attractant for many insect taxa, and it has a coattractive and synergistic effect when presented together with some other compounds (Yamazaki, 1998; Landolt et al., 2011; Landolt et al., 2013).

The combination of PEAA was reported to be superior to any of the single compounds in the tortricids $H$. nubiferana (Jósvai et al., 2016a) or C. splendana (Jósvai et al., 2016b), and similar results were recorded with the sesiid Synanthedon myopaeformis Borkh. (Tóth et al., 2012).

The aim of the present study was to reveal which other microlepidopterans are attracted to the PEAA lure in various biotopes. As a result, we could get a broader view of the microlepidopteran species in which PE and/or AA may play an important role in their chemical ecology. Since PEAA baited traps are recommended first of all for use in apple orchards managed by codling moth mating disruption, this information may become very useful when advising farmers for evaluating trap catches in traps under their own supervision.

\section{Materials and Methods}

\section{Details of field trapping tests}

Field trapping experiments were conducted in the course of 5 consecutive years in Hungary, at locations where high diversity of microlepidopteran species was presumed. The main experimental site was an abandoned orchard which was located near to a mixed oak forest, and additional experiments were set up next to or within mixed forest vegetation (Table 1). The following four treatments were compared in each experiment: PE on its own (6 mg, on rubber or polyethylene bag dispenser); AA on its own (400 mg; in polyethylene bag dispenser); PE (6 mg) and AA (400 mg) loaded into the same polyethylene bag dispenser and unbaited traps. The composition of PE and AA at this ratio was reported to be effective for some pest moths in earlier experiments (Tóth et al., 2012, 2014; Jósvai and Tóth, 2015). Synthetic PE (98\% general purity, minimum 92\% isomeric purity) was purchased from Bedoukian (Danbury, CT), while AA (purity 96\%) was obtained from Sigma-Aldrich (Budapest, Hungary). 


\section{Traps}

Two types of sticky traps were used:

- the CSALOMON® RAG (produced by Plant Prot. Inst., HAS, Budapest, Hungary), which has routinely been used for the trapping of many moths before (Szőcs, 1993; Tóth and Szőcs, 1993). Photos of the trap can be viewed at www.csalomontraps.com. The size of sticky insert of CSALOMON ${ }^{\circ}$ RAG trap was $10 \times 16 \mathrm{~cm}$.

- the ENL_RAG trap was an enlarged delta trap design, similar in shape and material (transparent PVC sheets) to the CSALOMON® RAG, except its extra sticky insert of $23 \times 36 \mathrm{~cm}$.

Sticky inserts of both of the two types of traps were replaced regularly at 7-10 days intervals to prevent the surface to become fully covered by insects.

Traps were set at a height of 1.5-1.8 m, attached to branches of trees or bushes. In each year, randomized complete block design was used with four blocks of traps. Traps within blocks were separated by $8-10 \mathrm{~m}$, and blocks were sited at least $30 \mathrm{~m}$ apart. As a rule, traps were inspected twice weekly, when captured insects were recorded, sexed (not in every experiment) and removed.

\section{Baits}

Polyethylene bag dispensers (for AA, PE and PEAA): A 1-cm piece of dental roll (Celluron ${ }^{\circledR}$; Paul Hartmann, Heidenheim, Germany) was placed into a tight polyethylene

Table 1

Field test details

\begin{tabular}{|c|c|c|c|c|}
\hline Experiment No. & Location & Description of orchards & Period & Trap type \\
\hline Exp. 1A & $\begin{array}{l}\text { Julianna-major, } \\
\text { Pest county }\end{array}$ & $\begin{array}{l}\text { abandoned backyard } \\
\text { mixed orchard }\end{array}$ & 20 April - 6 July, 2009 & RAG \\
\hline Exp. 1B & $\begin{array}{l}\text { Telki, Pest } \\
\text { county }\end{array}$ & $\begin{array}{l}\text { bushy edge of a } \\
\text { mixed oak forest }\end{array}$ & 21 April - 6 July, 2009 & RAG \\
\hline Exp. 2 & $\begin{array}{l}\text { Julianna-major, } \\
\text { Pest county }\end{array}$ & $\begin{array}{l}\text { abandoned backyard } \\
\text { mixed orchard }\end{array}$ & 25 May - 25 August, 2010 & RAG \\
\hline Exp. 3 & $\begin{array}{l}\text { Julianna-major, } \\
\text { Pest county }\end{array}$ & $\begin{array}{l}\text { abandoned backyard } \\
\text { mixed orchard }\end{array}$ & 16 May - 23 July, 2011 & RAG \\
\hline Exp. $4 A^{*}$ & $\begin{array}{l}\text { Julianna-major, } \\
\text { Pest county }\end{array}$ & mixed oak forest & 30 April - 30 August, 2012 & ENL_RAG \\
\hline Exp. 4B* & $\begin{array}{l}\text { Julianna-major, } \\
\text { Pest county }\end{array}$ & $\begin{array}{l}\text { abandoned backyard } \\
\text { mixed orchard }\end{array}$ & 30 April - 30 July, 2012 & ENL_RAG \\
\hline Exp. $5 A^{*}$ & $\begin{array}{l}\text { Julianna-major, } \\
\text { Pest county }\end{array}$ & mixed oak forest & 30 April - 13 August, 2013 & ENL_RAG \\
\hline Exp. $5 B^{*}$ & $\begin{array}{l}\text { Julianna-major, } \\
\text { Pest county }\end{array}$ & $\begin{array}{l}\text { abandoned backyard } \\
\text { mixed orchard }\end{array}$ & 30 April - 9 July, 2013 & ENL_RAG \\
\hline
\end{tabular}

* = PE was administered to polyethylene dispenser in these experiments 
sachet (ca. $1.5 \times 1.5 \mathrm{~cm}$ ) made of $0.02-\mathrm{mm}$ linear polyethylene foil. The dispenser was attached to a plastic strip $(8 \times 1 \mathrm{~cm})$ for easy handling when assembling the traps. For making up the baits, compounds were administered onto the dental roll and the opening of the polyethylene bag was heat-sealed. Previous results with acetic acid tested against other pests showed that this type of dispenser was active for several weeks of field exposure (i.e. Tóth et al., 2002, 2012, 2014); hence, we decided to renew the lures at 2 to 3 -week intervals.

Rubber dispensers (for PE): Lures for the tests were prepared by using pieces of rubber tubing (No. MSZ 9691/6; Taurus, Budapest, Hungary; extracted 3 times in boiling ethanol for $10 \mathrm{~min}$, then 3 times in methylene chloride overnight). We replaced these lures at 4-week intervals according to our earlier experience in experiments on codling moth with this lure (Tóth et al., 2014).

When making the lures, the required amounts of compounds were administered to the surface (rubber) or into the polyethylene bag dispensers in hexane solutions. After allowing the solvent to evaporate for $15 \mathrm{~min}$, the polyethylene bag dispensers were heat sealed. All types of dispensers were wrapped in aluminium foil and stored at $-30^{\circ} \mathrm{C}$ until use.

\section{Statistical analyses}

Statistical evaluation was conducted only in case the number caught from a given species exceeded a total of 10 moths in an experiment. Mean moth catches are reported for each treatment over the length of each experiments. Data were transformed using log $(\mathrm{x}+0.5)$ transformation to normalize them. Treatments with zero catch, together with catches not significantly different from zero, were separated in order to avoid zero variances (Student's $t$-test, $\mathrm{P}>0.05$ ). Normality was tested by Shapiro-Wilk's test and homogeneity of variances was checked by Fisher's F or Levene's test $(\mathrm{P}>0.05)$. Depending on the number of the remained treatments, data were analysed by Student's $t$-test (if it remained merely two groups) or by one-way ANOVA (in case of more than two groups were to compare). Having significant ANOVA result, treatment means were separated by Tukey's post-hoc test. Statistical procedures were conducted using the software packages IBM SPSS Statistic for Windows, Version 22.0 (Armonk, NY, IBM Corp.).

\section{Results}

Total number of moths caught varied highly between years and species, but there were 8 species from which traps caught more than 10 moths in each experiment, making worthwhile to perform statistical evaluation. These were Ypsolopha scabrella L. (Ypsolophidae); together with the tortricids: Archips crataegana Hübner, Archips rosana L., Archips xylosteana L., H. nubiferana, Notocelia trimaculana Haworth, Ptycholoma lecheana L. and Tortrix viridana L. By general tendency of catches, these could be divided into two groups: in the first group of moths the addition of AA to PE resulted in higher 
catches (H. nubiferana, Y. scabrella and $N$. trimaculana), while in case of the rest of the species, both PEAA and AA attracted similar numbers of the respective species.

Apart from microlepidoptera, several macrolepidoptera were also captured in our experiments; these data will be discussed in a separate publication.

\section{H. nubiferana}

Traps baited with PE or PEAA attracted significantly more $H$. nubiferana than the unbaited control in all of the experiments (Fig. 1). AA alone caught statistically more than unbaited in three experiments: Exps. 3, 4B and 5B. Except one experiment, significantly higher number of moths was recorded in PEAA-baited traps, than that of traps baited with PE or AA alone. However in Exp. 3, catches in PEAA-baited traps were the statistically the same as traps baited with PE alone. Female ratio in PEAA traps ranged between 27.2 and $44.6 \%$.

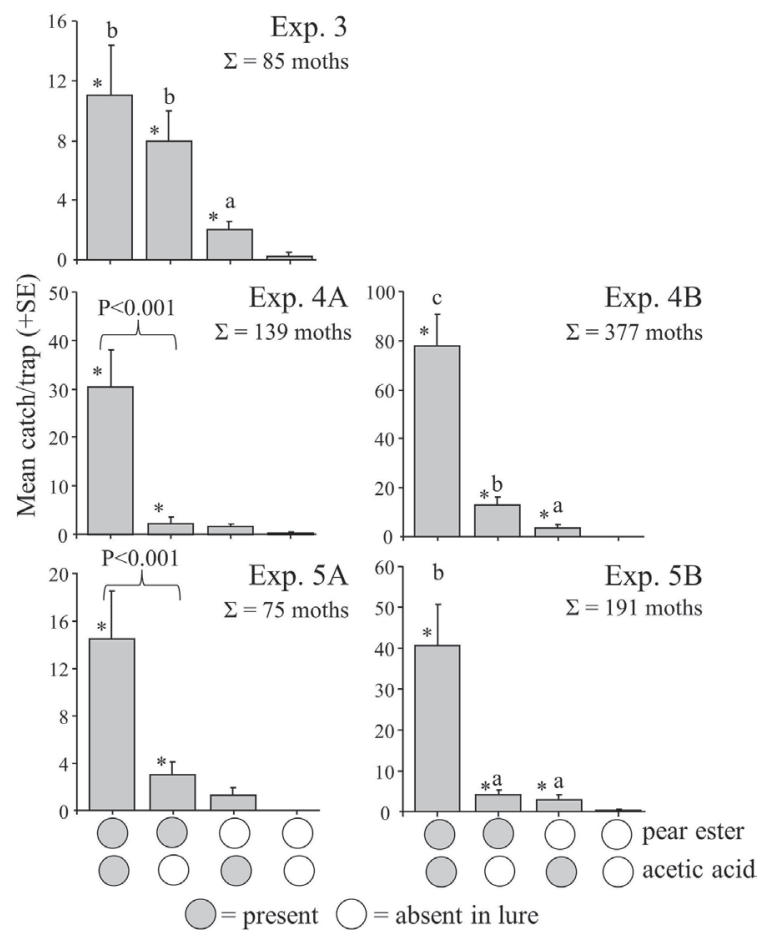

Fig. 1. Mean catches of Hedya nubiferana in traps baited with pear ester, acetic acid, their combination and in unbaited control traps. Columns with asterisk within one diagram differ significantly from unbaited control traps (Student's $t$-test, $\mathrm{P}<0.05$ ). P-value above the columns connected with a bracket derives from Student's $t$-test, NS indicates nonsignificant difference. Columns marked with the same letter are not significantly different (ANOVA, Tukey's post hoc $\mathrm{P}=0.05$ ) 
Y. scabrella

The species was captured in high numbers in Exps. 4A and 5A conducted in a mixed oak forest. In both tests, PEAA-baited traps attracted the highest number of moths, significantly more than unbaited traps (Fig. 2). Moths caught were sexed only in Exp. 5A, where $48.65 \%$ in PEAA-baited traps were females.

\section{N. trimaculana}

Highest numbers of $N$. trimaculana were recorded in Exps. 4A and 4B. While in Exp. 4A only PEAA-baited traps caught significantly more moths than unbaited traps, in Exp. 4B, traps baited either with PEAA or with PE alone attracted significantly more moths than unbaited traps (Fig. 2). Catches of PE and PEAA in Exp. 4B did not differ statistically. Moths were sexed in both experiments: PEAA-baited traps caught $44.4 \%$ and $47.3 \%$ females in Exp. 4A and 4B, respectively. Female ratio in PE-baited traps was $27.3 \%$ in the latter experiment.

\section{Archips spp.}

A. rosana moths were caught in Exps. 2, 5A and 5B. Traps baited with PEAA or AA caught the highest number of moths in each experiment, however, only catches of AA-baited traps differed significantly from unbaited in Exps. 5A and 5B (Fig. 3). Moths

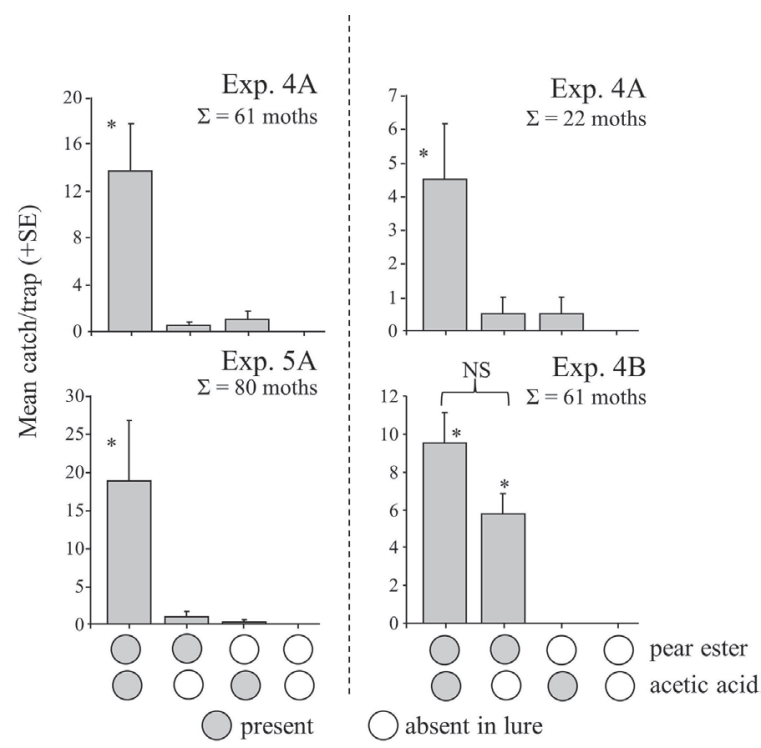

Fig. 2. Mean catches of Ypsolopha scabrella and Notocelia trimaculana in traps baited with pear ester, acetic acid, their combination and in unbaited control traps. For significance, refer to Fig. 1 
were sexed only in Exp. 2, where $31.58 \%$ of moths caught with PEAA-baited traps were female.

In Exps. 2 and 4A, neither of the treatments caught significantly more Archips crataegana than unbaited control, although numerically moth numbers in the two treatments containing AA (PEAA, AA) were the highest. Mean number ( \pm SE) was $2.5 \pm 1.2$ in traps baited with PEAA, while $1.3 \pm 1.0$ with AA in Exp. 2. Unbaited traps or traps with PE caught nil and a total of 15 moths were caught in this experiment. In Exp. 4A, mean number of moths $( \pm \mathrm{SE})$ was $2.0 \pm 1.2,0.3 \pm 0.3,2.8 \pm 1.3$ and $0.0 \pm 0.0$ in traps baited with PEAA, PE, AA and unbaited, respectively; a total of 20 moths were caught. Moths caught were sexed only in Exp. 2 and $6.67 \%$ were female.

In case of Archips xylosteana, in Exp. 1A, significantly more moths were recorded in AA- and PEAA-baited traps than in unbaited ones, and AA caught almost 6 times more moths than PEAA (Fig. 3). In Exp. 2, only catches of PEAA traps were significantly higher than unbaited control. Moths caught were sexed only in Exp. 2, where $5.5 \%$ of the moths caught in PEAA traps were female.

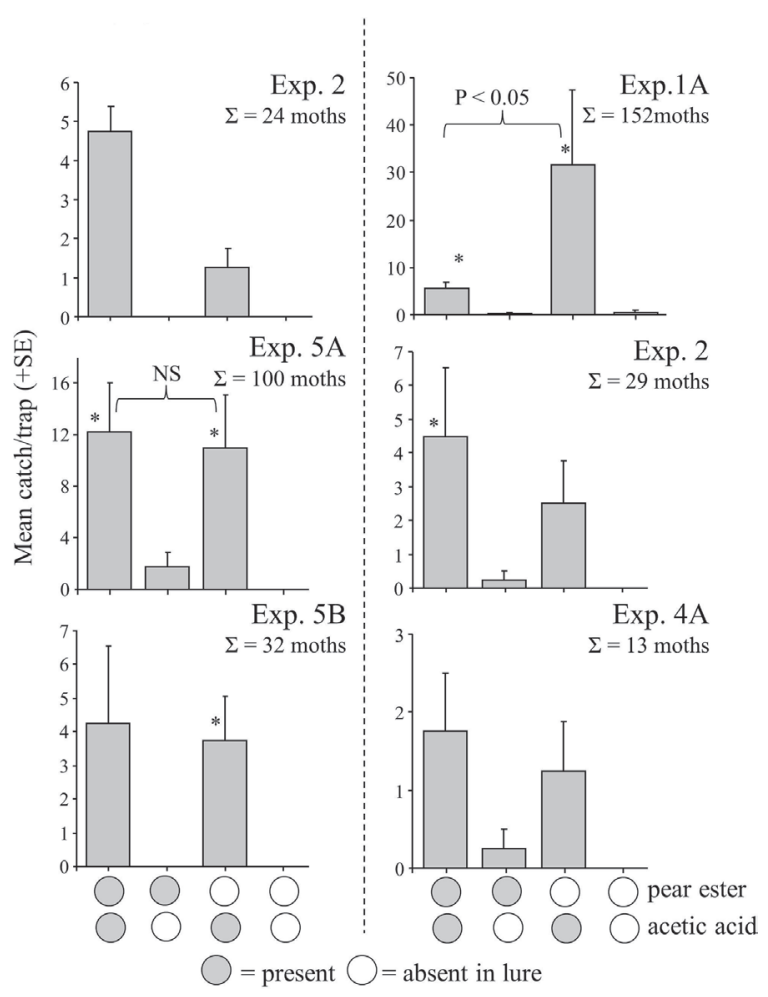

Fig. 3. Mean catches of Archips rosana and Archips xylosteana in traps baited with pear ester, acetic acid, their combination and in unbaited traps. For significance, refer to Fig. 1. 
P. lecheana

PEAA- and AA-baited traps in Exps. 1B, 4A and 4B caught significantly more of $P$. lecheana than unbaited control (Fig. 4). In all of these experiments, catches in traps baited with AA and PEAA did not differ statistically, except in Exp. 4B, where significantly more moths were recorded with PEAA (Fig. 4). Female ratio ranged between 4.16 and $24.05 \%$ in AA-baited traps, while this ratio was between 0 and $57.14 \%$ in PEAAbaited traps.

\section{T. viridana}

In all four experiments, at least one treatment caught significantly more $T$. viridana than unbaited control (Fig. 5). In Exp. 1A, 4A and 5A catches in both AA and PEAA differed significantly from unbaited traps, but not from each other. Caught moths were sexed only in two experiments. While in Exp. 2 female ratio was $65.26 \%$ in AA- and $40 \%$ in PEAA-baited traps, no females were caught in Exp. 5A.

\section{Discussion}

The synergistic activity of AA when added to PE in H. nubiferana has been demonstrated earlier (Jósvai et al., 2016a) and our supplementary results showed here (Fig. 1) clearly confirmed the results of this previous report.

The general tendency of catches in the present study strongly suggested that the presence of both PE and AA was necessary for best attraction of Y. scabrella. No other information on the attraction of $Y$. scabrella to other synthetic compounds is available from the literature. To the best of our knowledge, this is the first report on the attraction of PEAA for an ypsolophid.

Distribution of catches of $N$. trimaculana has a similar character to those of Y. scabrella with catches of PEAA lures always sticking out, despite the fact that differences from single compounds were not always significant. Thus, it appears that this may be a further species where both PE and AA had importance in the chemical ecology.

Considering their responses to PE being synergized by the addition of AA, both $Y$. scabrella and N. trimaculana appear to be similar to the tortricids $C$. pomonella (Landolt et al., 2007), C. splendana (Jósvai et al., 2016b), H. nubiferana (Jósvai et al., 2016a) and to the sesiid S. myopaeformis (Tóth et al., 2012). Consequently, the number of families where field activity of PE has been demonstrated increased to three. This suggests that PE may play a role in the chemical ecology of different lepidopterous groups in a more widespread manner than it was thought before.

There is little information on the behaviour of $Y$. scabrella and $N$. trimaculana. It is known that pear and apple both belong to the range of their host plants (Mészáros et al., 1995). Pear ester therefore could also have a role in host plant finding behaviour for these moths, as it is supposed in case of the other species attracted to pear ester-containing lures (see introduction). 
The rest of the tortricid moths caught in this study (A. rosana, A. crataegana, A. xylosteana, P. lecheana and T. viridana) were all probably responding to only AA, since there were no differences between catches of AA or PEAA in the experiments, and the presence of PE did not seem to interfere with activity of AA.

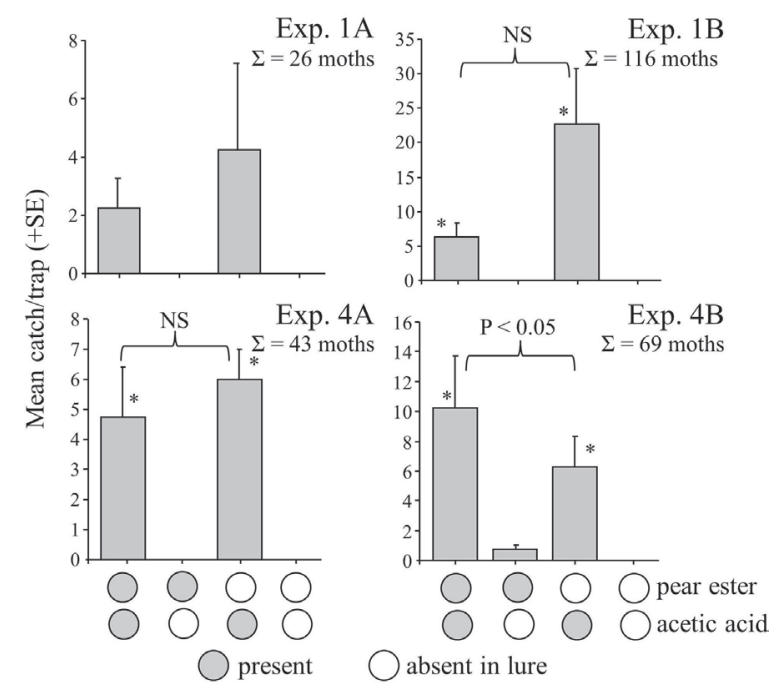

Fig. 4. Mean catches of Ptycholoma lecheana in traps baited with pear ester, acetic acid, their combination and in unbaited control traps. For significance, refer to Fig. 1

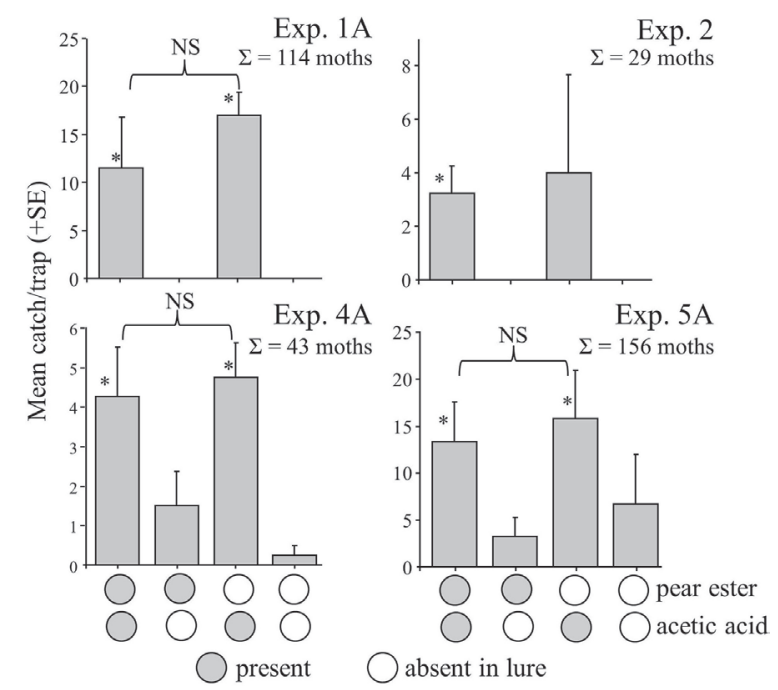

Fig. 5. Mean catches of Tortrix viridana in traps baited with pear ester, acetic acid, their combination and in unbaited control traps. For significance, refer to Fig. 1 
Feeding behaviour of adult moths on sugar sources (floral and extrafloral plant nectars, saps, honeydew, fruits and fruit juices) is well documented (Norris, 1936; ElSayed et al., 2005; Wenninger and Landolt, 2011). Many insect species of different taxonomic groups were reported to be attracted to AA or baits containing AA together with synthetics present in fermented molasses or floral volatiles (see for example Landolt et al., 2011). AA may be a general indicator or cue of sugar-rich materials that are colonized by microbes (Landolt et al., 2013). As for other tortricids, lures containing AA have been reported to attract Choristoneura rosaceana Harris, Pandemis pyrusana Kearfott and Spilonota ocellana Den. and Schiff., and the presence or absence of PE did not seem to influence catches (Knight et al., 2014).

All 8 moth species reported on in this study, namely Y. scabrella, A. rosana, A. crataegana, A. xylosteana, H. nubiferana, P. lecheana, T. viridana, and N. trimaculana are known to be pest species in Hungary (Mészáros et al., 1995). They belong to the so-called spring aspect of leafrollers, damaging their host plants early in the season: their larvae feed on buds, leaves and young fruits of their host plants which include several cultivated plant species (apple, quince, cherry, pear, etc.). Although they rarely cause serious damage, in outbreak years control sprayings are necessary. Moreover, the overall decrease of the application of insecticides and advent of species specific management against the main pest of different orchard trees through mating disruption with the respective pheromone could result in more frequent outbreaks of these secondary pests in the future (Witzgall et al., 2010; Porcel et al., 2013).

PEAA lures have already been applied in codling moth management (Witzgall et al., 2008; Knight, 2010). The fact, that PEAA lures are capable to attract further pest moths as well, may make the lures more preferable in future management applications. On the other hand, the capture of these moths in the traps raises the need for some taxonomic knowledge in evaluating captures in PEAA-baited traps.

As the PEAA lure attracts not only males, but also females in high percentage, it possesses all the advantages of a female-targeted lure (Knight and Light 2005a), potentially for all the moth pests reported in this study.

\section{Acknowledgement}

Research presented was partially supported by OTKA grant PD 115938 of HAS to SK.

\section{Literature}

Berger, R. G., Drawert, F. and Schraufsteller, B. (1984): Natural occurrence of octanoic-, decenoic-, and decadienoic acid ethyl esters in red delicious apples. Z. Lebensm. Unters. Forsch. 178, 104-105.

Coracini, M., Bengtsson, M., Liblikas, I. and Witzgall, P. (2004): Attraction of codling moth males to apple volatiles. Entomol. Exp. Appl. 110, 1-10.

El-Sayed, A. M., Heppelthwaite, V. J., Manning, L. M., Gill, A. R. and Suckling, D. M. (2005): Volatile constituents of fermented sugar baits and their attraction to Lepidopteran species. Agric. Food Chem. 53, 953-958.

Jennings, W. G., Creveling, R. K. and Heinz, D. E. (1964): Volatile esters of Bartlett pear. IV. Esters of trans: 2-cis 4-decadienoic acid. J. Food Sci. 29, 730-734. 
Jósvai, J. K. and Tóth, M. (2015): Pear ester-based lure attracting a butterfly Peary Heath (Coenonympha arcania L.). $31^{\text {st }}$ Conference for the ISCE, Stockholm, Sweden, 29 June - 23 July, 2015, Abstract book, $418 \mathrm{p}$.

Jósvai, J. K., Koczor, S. and Tóth, M. (2016a): Traps baited with pear ester and acetic acid attract both sexes of Hedya nubiferana (Lepidoptera: Tortricidae). J. App. Ent. 140, 81-90.

Jósvai, J. K., Voigt, E. and Tóth, M. (2016b): A pear ester-based female-targeted synthetic lure for the chestnut tortrix (Cydia splendana Hübner). Ent. Exp. App., accepted.

Knight, A. L. (2010): Improved monitoring of female codling moth (Lepidoptera: Tortricidae) with pear ester plus acetic acid in sex pheromone-treated orchards. Environ. Entomol. 39, 1283-1290.

Knight, A. L. and Light, D. M. (2005a): Timing of egg hatch by early-season codling moth (Lepidoptera: Tortricidae) predicted by moth catch in pear ester- and codlemone-baited traps. Can. Entom. 137, 728-738.

Knight, A. L. and Light, D. M. (2005b): Use of ethyl (E,Z)-2,4-decadienoate in codling moth management: kairomone species specificity. J. Entomol. Soc. Brit. Columbia 101, 61-67.

Knight, A. L., Hilton, R., Basoalto, E. and Stelinski, L. L. (2014): Use of glacial acetic acid to enhance bisexual monitoring of tortricid pests with kairomone lures in pome fruits. Environ. Entomol. 43, $1628-1640$.

Landolt, P. J. and Guédot, Ch. (2008): Field attraction of codling moth (Lepidoptera: Tortricidae) to apple and pear fruit, and quantitation of kairomones from attractive fruit. Ann. Entomol. Soc. Am. 101, $675-681$.

Landolt, P., Suckling, D. M. and Judd, G. J. R. (2007): Positive interaction of a feeding attractant and a host kairomone for trapping the codling moth, Cydia pomonella (L.). J. Chem. Ecol. 33, 2236-2244.

Landolt, P. J., Adams, T., Zack, R. S. and Crabo, L. (2011): A diversity of moths (Lepidoptera) trapped with two feeding attractants. Ann. Entom. Soc. Am. 104, 498-506.

Landolt, P. J., Tóth, M., Meagher, R. L. and Szarukán, I. (2013): Interaction of acetic acid and phenylacetaldehyde as attractants for trapping pest species of moths (Lepidoptera: Noctuidae). P. Man. Sci. 69, 245-249.

Light, D. M. and Knight, A. L. (2005): Specificity of codling moth (Lepidoptera: Tortricidae) for the host plant kairomone, ethyl (2E,4Z)-2,4-decadienoate: field bioassays with pome fruit volatiles, analogue, and isomeric compounds. J. Agric. Food Chem. 53, 4046-4053.

Light, D. M., Knight, A. L., Henrick, C. A., Rajapaska, D., Lingren, B., Dickens, J. C., Reynolds, K. M., Buttery, R. G., Merrill, G., Roitman, J. and Campbell, B. C. (2001): A pear-derived kairomone with pheromonal potency that attracts male and female codling moth, Cydia pomonella (L.). Naturwissenschaften 88, 333-338.

Mészáros, Z., Reichart, G., Balázs, K., Deseő, K., Huzián, L. and Nagy, B. (1995): Rend: Lepkék - Lepidoptera [Order: Butterflies - Lepidoptera]. In: T. Jermy and K. Balázs (eds): A növényvédelmi állattan kézikönyve. 4/A. [Handbook of Agricultural Entomology], Akadémiai Kiadó, Budapest, Vol. 4/A, pp. 17-445. (in Hungarian).

Norris, M. J. (1936): The feeding habits of the adult Lepidoptera: Heteroneura. Transactions of the Entomol. Soc. Lon. 85, 61-90.

Porcel, M., Sjöberg, P., Swiergiel, W., Dinwiddle, R., Rämert, B. and Tasin, M. (2013): Mating disruption of Spilonota ocellana and other apple orchard tortricids using a multispecies reservoir dispenser. Pest Manag. Sci. 71, 562-570.

Roelofs, W., Comeau, A., Hill, A. and Milicevic, G. (1971): Sex attractant of the codling moth: characterization with electroantennogram technique. Science 174, 297-299.

Schimizu, S. and Yoshihara, S. (1977): The constituents of the essential oil from Japanese quince fruit, Cydonia oblonga Miller. Agric. Biol. Chem. 41, 1525-1527.

Schmidt, S., Anfora, G., Ioriatti, C., Germinara, G. S., Rotundo, G. and De Cristofaro, A. (2007): Biological activity of ethyl $(E, Z)$-2,4-decadienoate on different tortricid species: electrophysiological responses and field tests. Environ. Entomol. 36, 1025-1031.

Szőcs, G. (1993): Feromoncsapdák a magyar piacon (Pheromone traps on the Hungarian market). Növényvédelem 29, 191-193. (in Hung.). 
Tóth, M. and Szőcs, G. (1993): Feromonkutatásaink másfél évtizede az MTA Növényvédelmi Kutatóintézetében (One and a half decade of pheromone studies at the Plant Protection Institute of the Hungarian Academy of Sciences). Növényvédelem 29, 101-109. (in Hung.)

Tóth, M., Répási, V. and Szöcs, G. (2002): Chemical attractants for females of pest pyralids and phycitids (Lepidoptera: Pyralidae, Phycitidae). Acta Phytopathol. et Entomol. Hung. 37, 375-384.

Tóth, M., Landolt, P., Szarukán, I., Szólláth, I., Vitányi, I., Pénzes, B., Hári, K., Jósvai, J. K. and Koczor, S. (2012): Female-targeted attractant containing pear ester for Synanthedon myopaeformis. Entomol. Exp. Appl. 142, 27-35.

Tóth, M., Jósvai, J., Hári, K., Pénzes, B., Vuity, Zs., Holb, I., Szarukán, I., Kecskés, Zs., Dorgán-Zsuga, I., Koczor, S. and Voigt, E. (2014): Pear ester based lures for the codling moth Cydia pomonella L. - A summary of research efforts in Hungary. Acta Phytopathol. et Entomol. Hung. 49, 37-47.

Utrio, P. and Eriksson, K. (1977): Volatile fermentation products as attractants for Macrolepidoptera. Ann. Zool. Fennici 14, 98-104.

Wenninger, E. J. and Landolt, P. J. (2011): Apple and sugar feeding in adult codling moths, Cydia pomonella: effects on longevity, fecundity, and egg fertility. J. Ins. Sci. 11, 161. doi: 10.1673/031.011.16101.

Witzgall, P., Stelinski, L., Gut, L. and Thomson, D. (2008): Codling moth management and chemical ecology. Ann. Rev. Entomol. 53, 503-522.

Witzgall, P., Kirsch, P. and Cork, A. (2010): Sex pheromones and their impact on pest management. J. Chem. Ecol. 36, 80-100.

Yamazaki, K. (1998): Communities of early spring noctuid and thyatirid moths (Lepidoptera: Noctuidae). Environ. Entomol. 26, 1283-1290. 